

RESEARCH ARTICLE

\title{
A DIAGNOSTIC ANALYSIS OF STRENGTHS WEAKNESS OPPORTUNITIES AND CHALLENGES OF FARMER INTEREST GROUP OF GUAVA IN DINDUGUL DISTRICT.
}

"M. R. Naveen kumar ${ }^{1}$ and T. Rathakrishnan" ${ }^{2}$.

1. Ph.D. Scholar, Department of Agricultural Extension and Rural Sociology, Tamil Nadu Agricultural University, Coimbatore.

2. Professor (Agricultural Extension), Thangapazham Agricultural College, Thirunelveli.

\section{Manuscript Info}

Manuscript History

Received: 8 May 2017

Final Accepted: 10 June 2017

Published: July 2017

Key words:-

Shared goal and interest, investigative study and SWOC.

\section{Abstract}

A Farmer Interest Group (FIG) is a self-managed, independent group of farmers with a shared goal and interest, their activities shall be limited only by the needs and motivation of group members' itself. FIGs have the power to create a socio - economic resolution in the rural areas of our country by producing tangible social assets. Due to its' long implementation period and gaining importance of group approaches, now it is opt time to perform a investigative study on strengths, weaknesses, opportunities and challenges of FIG. This study was conducted in Dindigul district. Five villages namely Old ayakudi, Vaeppanvalasu, Eramanayackanpatty, TKN pudhur and Rookvarpatty were selected deliberately due to the well-functioning of FIGs in and around. A total of one hundred respondents were selected at the rate of ten members from each group using simple random sampling technique. The open-ended empathical questions on their own perception on FIG were inquired and the responses were recorded and classified on it's form under the labels of strengths, weaknesses, opportunities and challenges (SWOC) for the existing FIG. The major strength, weakness, opportunity and challenge are found as good rapport building among members of FIG (55\%), lack of record maintenance and skill regarding organizing meetings (52\%), vast scope of implementation of value addition units like pulp industry and guava powder plants $(48 \%)$ and organizing producers at the operational time of FIG activities (33\%) and raising seed money among FIG members (25\%) respectively.

Copy Right, IJAR, 2017,. All rights reserved.

\section{Introduction:-}

FIG is registered informally under the state department of agriculture or horticulture on the basis of the nature of the FIG. It will be either formed by the local villagers on their own for risk sharing in farming or by the efforts of some cosmopolites such as NGOs, state agriculture department for the provision of government benefits to the FIG and develop the group as a representative ones in the villages. The types of activities that a FIG can undertake are limited only by the needs and motivation of group members. Some of the major activities are, engage in information sharing within the group and other groups as well, develop market networks and make market assessments and invest in issues that cannot be covered by individuals. 
SWOC analysis is a planning tool used to understand the Strength, Weaknesses, Opportunities and Challenges involved in a person, project, or in a business. It is defined as a process of generating information that is helpful in matching an organization or group's goals, programs and capacities to the social environment in which it operates. Hence for future upscaling of FIGs a clear understanding on existing strengths, weakness, opportunities and challenges in it is necessary, this research is believed to satisfy those requisites.

\section{Literature Relevance:-}

Manimekalai (2004) found that in this twenty - first century, we must take along an active people-centered and growth oriented poverty alleviation strategy - a strategy which seems to incorporate women's aspirations, dynamism and involvement. It is envisaged that self-help groups will play a vital role in such strategy. But there is a need for structural orientation of the groups to suit the requirements of new business.

Asokhan (2006) stated that majority of the respondents suggested that they should be free without any political involvement $(84.00 \%)$. Three-fourth $(75.66 \%)$ of them expressed that they need training to be organized at local level. Similar percentage (74.33\%) also expressed that the products are to be purchased by the government on contract basis. Other suggestion is that reduced interest rate for proper repayment of loans by the group members $(70.33 \%)$.

Mary (2009) suggested the leadership development through rotation of responsibilities among the members, conducting systematic evaluation of the performance of SHG, tapping alternate credit delivery system, providing intensive need based and skill oriented training, breaking cultural, social barriers and inhibitions to enhance selfdevelopment and instill a sense of self confidence among rural population..

Meenakshi (2011) suggested that enhancing the loan amount (92.50\%), low interest rate for long credit facilities $(85.83 \%)$, simplify the loan procedures $(80.00 \%)$ and marketing arrangement at taluk and district levels $(72.50 \%)$ would pay way for group's upliftment.

Ayyappan (2014) insisted some suggestions for effective functioning of SHGs. Majority of the SHGs women suggested enhancing the loan amount standardization for SHGs products $(85.00 \%)$, low interest rate for long term credit facilities (79.16\%), capacity building trainings (73.33\%) organize exhibition for displaying SHG's products through government market structure $(75.00 \%)$, information on banking $(74.16 \%)$ and leadership skill development training $(66.66 \%)$ for their empowerment.

\section{Methodology:-}

For this study, Ex-post facto research design was followed. Dindigul district of Tamil Nadu was purposively selected for the effective functioning of the Farmers' Interest Group on Guava in Old ayakudi of Palani block. Old Ayakudi Guava market is one of the well-known guava markets in South India. Palani block was selected due to more farm holdings under guava and large number of guava growers. One hundred respondents were selected at the rate of ten members from each group using simple random sampling technique in the villages namely Old ayakudi, Vaeppanvalasu, Eramanayackanpatty, TKN pudhur and Rookvarpatty.. The data collection was done with the help of a well-structured interview schedule that was pre-tested in Theni district on the banana growers group were revised and used for the research. The various open-ended multiple responses on SWOC were recorded and based on percentage analysis tool the best responses were separated and accounted for the study.

\section{Findings and Discussion:-}

Strengths:- Good rapport building among members of FIG (55\%), geographically conducive climate and soil suitability for guava production (40\%), mass dissemination of desired technology in no time to the agrarian society (36\%), acquirement of social status (32\%) and ensuring social cohesion (29\%) were the identified strengths.

Weaknesses:- Lack of record maintenance and skill regarding organizing meetings leading to conflicts among FIG officials and FIG members (52\%), dominance of few individuals in FIG lacks credibility among FIG members (40\%) and Joining up in FIG for fulfillment of their own needs (34\%) deteriorates the objective of entire FIG.

Opportunities:- Vast scope of implementation of value addition units like pulp industry and guava powder plants (48\%), scope of improvising the supply chain like exporting both the raw product and processed product (35\%), 
possibility of creation of shared infrastructural facilities like cold storage units for ensuring year around availability of produce (28\%) and learning up of new technologies by exposure visits in FIG (25\%) are the opportunities to be utilized in future.

Challenges: Organizing producers at the operational time of FIG activities (33\%), raising seed money among FIG members $(25 \%)$ and acquiring matching grant from the State Dept. of Agri. and Horti. (25\%), identification of efficient non self-centered leaders of FIG (20\%) and withstanding the exploitation by causal agents such as wholesalers, commission agents and several in-group impediments (18\%) are yet to be win over tasks of FIG.

\section{Conclusion:-}

The frequent meetings that indeed creates a constructive "we feeling" may be the reason for the persistence of good rapport building among members of FIG. As most of the FIG members completed primary and secondary education, their record maintenance proficiency and skill regarding organizing meetings are somewhat less which leads to conflicts among FIG officials and FIG members. The FIG members perceived vast scope for implementation of value addition units like pulp industry and guava powder plants as the major opportunity itself through several meetings and exhibitions conducted by the state department of agriculture. FIG members being occupied their selves in several farming and non-farming occupations doesn't permit them to assemble at a common place in a common time, this in turn leads to less attendance on the demonstrations and meetings concerned with new innovative technologies and practices. Hence, obtaining the seed money from the government is also an lengthier process to win over in the mere future. Government's policy makers should consider the relevant research studies on farmer groups to understand the grass root level difficulties, which aside strengthen the farmer empowerment infrastructure in our agrarian nation.

\section{References:-}

1. Asokhan, M. 2006. Empowerment of Rural Women through Self Help Groups - An Empirical Analysis. Unpub. Ph.D. Thesis, AC\&RI, TNAU, Coimbatore.

2. Ayyappan, N. 2014. Developing Integrated Module for Effective Functioning of Tribal Women SHG's and Their Empowerment. Unpub. M.Sc. (Ag.) Thesis, AC\&RI, TNAU, Madurai.

3. Manimekalai, N. 2004. Impact of Various forms of Micro Financing on Women - Report of Department of Women and Child Development. Ministry of Human Resource Development, Government of India, New Delhi.

4. Mary, K. J. 2009. Role of Tank Irrigation System in Sustaining the Livelihood Status of the SHG's: A Case Study. Unpub. M.Sc. (Ag.) Thesis, AC\&RI, TNAU, Coimbatore.

5. Meenakshi, V. 2011. Participation and Empowerment of Rural Women In Self Help Groups - An Analysis. Unpub. M.Sc. (Ag.) Thesis, AC\&RI, TNAU, Coimbatore. 